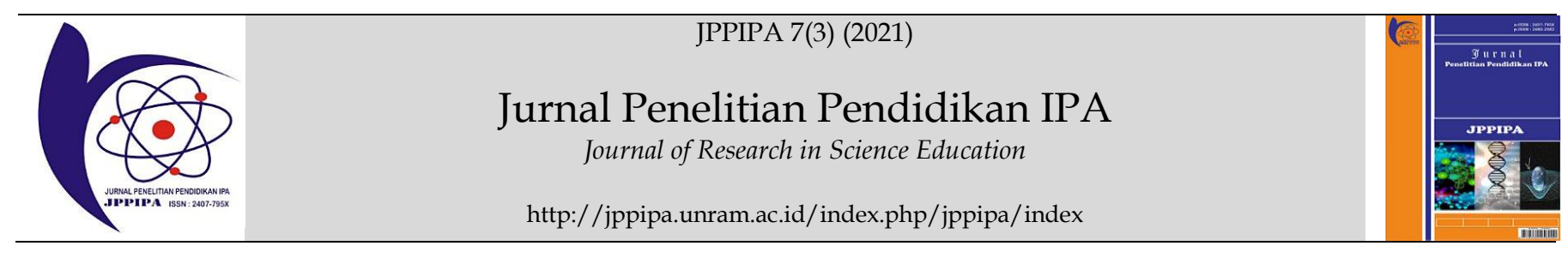

\title{
Fabrication of Digital Harmonic Vibration Practicum Using Phototransistor Sensor with Arduino-Uno Microcontroller
}

\author{
Marjoni Imamora Ali Umar ${ }^{1 *}$, Dany Kurniawan ${ }^{1,2}$, Novia Lizelwati ${ }^{1}$ \\ ${ }^{1}$ Department of Physics Education, Faculty of Tarbiyah and Teacher Training, State Islamic Institute (IAIN) Batusangkar, Batusangkar 27213, \\ West Sumatra, Indonesia. \\ ${ }^{2}$ Science teacher at SDN 09 Paninggahan Kec. Junjung Sirih Kab. Solok.
}

DOI: $10.29303 /$ jppipa.v7i3.835

\section{Article Info}

Received : June $20^{\text {th }}, 2021$

Revised : July 14th, 2021

Accepted: July 16 $16^{\text {th }}, 2021$

\begin{abstract}
The problem in the harmonic vibration practicum is in calculating time accurately. Commonly, the time counter used was a stopwatch, but it was unable to provide valid data. As a result, the student has difficulty seeing the relationship between concepts with practical results in the laboratory. To overcome these problems, in this study, we developed a harmonic vibration practicum tool that is equipped with a digital timer using an Arduino Uno microcontroller as a light sensor. An Arduino can be programmed via a PC according to the wishes of the developer. This study was development research using a 4-D model (Define-design-develop-dissemination). The define and design stages respectively to find problems in the harmonic vibration practicum tool. The tool is finally designed and then calibrated, validated, and practical. The calibration results show that the percentage difference for repetition measurement and comparison that values with theory was $0.008 \%$ and $3.98 \%$, respectively. In addition, the validation results show an average percentage of $87 \%$ or very valid. For practicality, the result through a limited test of Physics students of IAIN Batusangkar in the second semester shows a very practical response with a percentage of $85.96 \%$. Due to time constraints, the dissemination stages have not been carried out in this study.
\end{abstract}

Keywords: Harmonic vibration; Arduino Uno; Microcontroller; stopwatch

Citation Umar, M.I.A., Kurniawan, D., \& Lizelwati, N. (2021). Fabrication of Digital Harmonic Vibration Practicum Using Phototransistor Sensor with Arduino-Uno Microcontroller. Jurnal Penelitian Pendidikan IPA, 7(3), 468-473. doi:https:// doi.org/10.29303/jppipa.v7i3.835

\section{Introduction}

The concept of physics was built from experiments that gave birth to statements, formulations, and lastly, it rose the concept. In addition, experiments conducted by practitioners are also useful for proving existing theories. To generate and prove the correct concept, we need a practical tool that is also valid and fast response to changes in physical quantities that exist during the practicum or experiment (Harmita, 2012). To carry out practical easily with high data accuracy, it is necessary to develop practicum tools such as changing shapes, simplifying processes, digitizing time recording, and others (Trianto, 2009). Especially for time recording tools, practicum tools in schools and universities still use a lot of "stopwatches", where the "start/on" and "stop/off" buttons are pressed at the beginning and the end of the practicum process.

Among the practicum equipment in schools that require time during the experimental process is straight motion changing regularly (GLBB) (Deesera et al., 2017), free fall movement (GJB) (Maiyena, Imamora, \& Ningsih, 2018), simple harmonic motion (GHS) (Dewi, 2014), viscosity, etc. In the GHS experiment, the time of one vibration was recorded by using the manual stopwatch. This condition needs to be optimized because if we use a stopwatch for a short track, the time recording is less accurate and causes large errors in the 
measurement. Normally, the start button of stopwatch is pressed when the pendulum is released and pressed again to stop when the pendulum has swung as much as desired. This condition is prone to errors because if the practitioner is late in pressing the start or stop button, it will cause large errors, especially in time recording (Farasdaq; Humaira, 2016).

Developments that have been carried out by Sukindar, Kartika, and Untoro (2017) using a phototransistor sensor with an Arduino microcontroller for the experiment of the moment of inertia. We categorized these practicum tools as good according to several media, materials, and physics teachers. The Arduino sensor used is an electronics kit as the key component where it can be programmed using a computer (Syahwil, 2013). If the sensor is installed as a timer in the GHS experiment, we positioned the sensor in the middle of the pendulum. If the object passes through the sensor three times, it is equal to one vibration. This is done repeatedly with as many vibrations as desired, and then the recorded time will be displayed on the LCD screen. With such developments, it is hoped that the GHS experiment can provide accurate data and successfully prove the theory.

Based on this phenomenon, it is reported that we have developed a digital GHS (DGHS) practicum tool that was facilitating recording time. A DGHS practicum tool has been developed by using an Arduino-based phototransistor sensor and has received recognition as a validity, practicality tool (Riduwan, 2010) and a very convincing calibration tool. This is proven by the truth of the data generated from the practicum and validated by three validators giving a very valid assessment with an average percentage of $87 \%$. Meanwhile, in terms of the practicality of the DGHS practicum tools obtained from the responses of the second-semester Physics students of IAIN, Batusangkar also gave an assessment that the DGHS practicum tools developed were very practical to use with a percentage of $85.96 \%$.

\section{Method}

This research is a Research and Development (R\&D using a 4-D model developed by Thiagarajan, which consists of (1) definition, 2) design, 3) development and 4) dissemination. Technically, these four steps are described in Figure 1. At the definition stage, the condition of the simple harmonic vibration (GHS) practicum tool has been known that needs to be developed to produce a valid and practical tool. At the design stage, a phototransistor circuit schematic is described as a timer sensor used. The installation of the circuit components to the PCB board using solder, and we paired the components as in Table 1. Lastly, we then connected to the Arduino Uno (Rinanthy, 2016) before placing it in the packaging (see Figure 2).

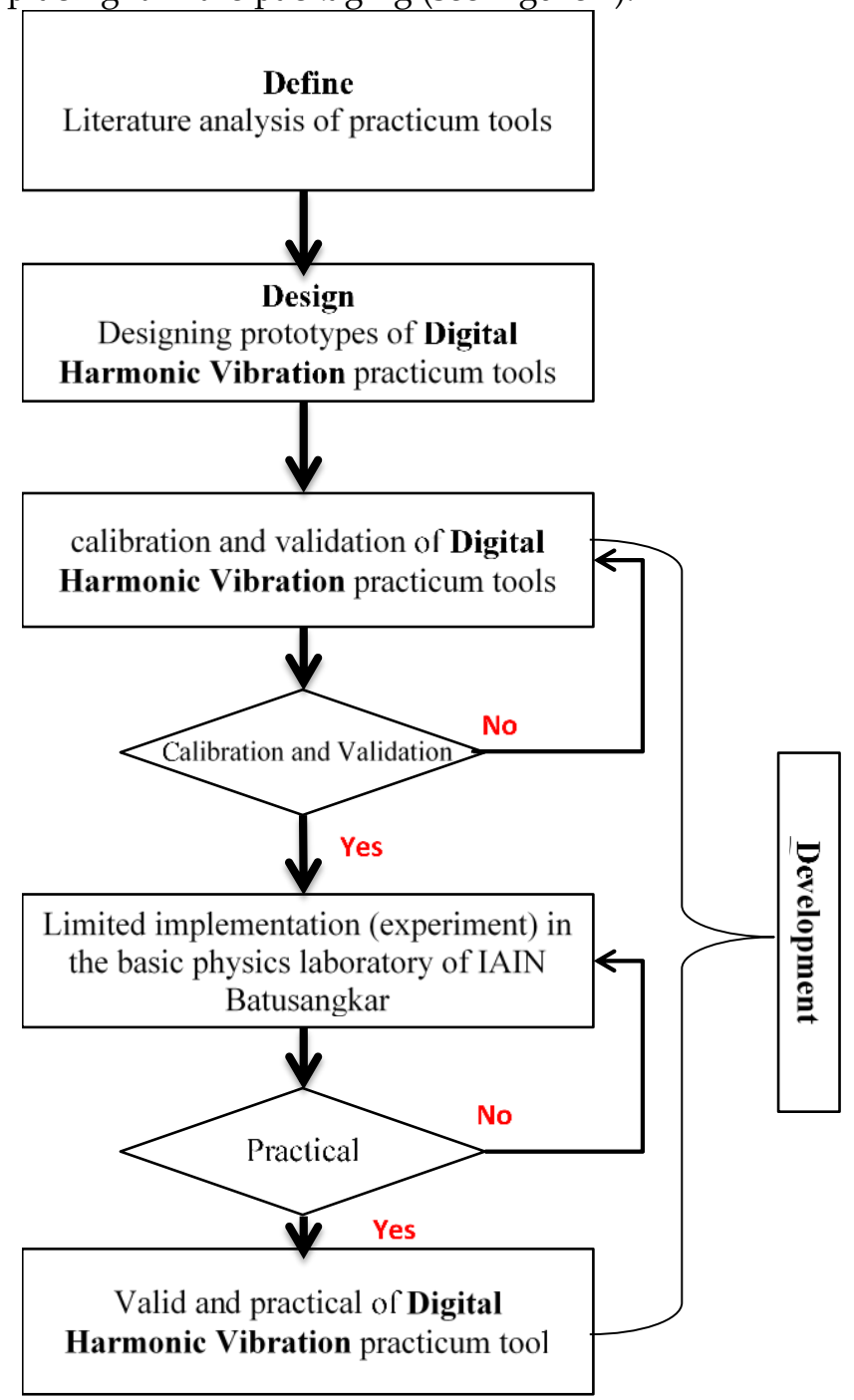

Figure 1. The development stage of the digital harmonic vibration practicum tool.

The calibration test is one of the steps in the development stage besides validating and practicality. This calibration is useful for proving the value of the acceleration of gravity from the data obtained from the DGHS practicum tool comparing with the earth's gravity $\left(9.8 \mathrm{~m} / \mathrm{s}^{2}\right)$. There are some calibrated aspects, namely frequency of use, data stability, usage conditions, and error limits. We validated this DGHS tool in 2 fundamental aspects, including content validation and construct validation. Content validation should determine whether the resulting DGHS practicum tool is under the concept of gravity. Meanwhile, construct validation aims to see the suitability of the practical tools with the basic competencies that have been set. Experts carried validation out by filling out a validation sheet. In the last stage, we also conducted the response test of physics students at IAIN Batusangkar in the second semester on the practicality of the DGHS practicum tool. 
Table 1. Tools and materials are needed in the development of DGHS practicum tools (Humaira, 2016).

\begin{tabular}{llll}
\hline No & Tool & Specification & $\begin{array}{l}\text { Number } \\
\text { of units })\end{array}$ \\
\hline 1 & Resistor & $220 \Omega$ & 6 \\
2. & Resistor & $10 \mathrm{k} \Omega$ & 2 \\
3. & Resistor & $82 \Omega$ & 1 \\
4. & Resistor & $300 \Omega$ & 2 \\
5. & Transistor & $2 \mathrm{~N} 3906$ & 1 \\
6. & Phototransistor & - & 1 \\
7. & Infrared Diode & - & 1 \\
8. & IC & NE 555 & 1 \\
9. & Microcontroller & Arduino Uno & 1 \\
10. & LED & Orange color & 4 \\
11. & Switch & On/Off & 3 \\
\hline & & & \\
\hline
\end{tabular}

A

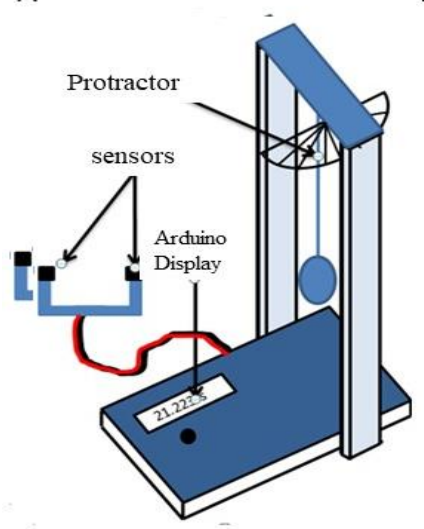

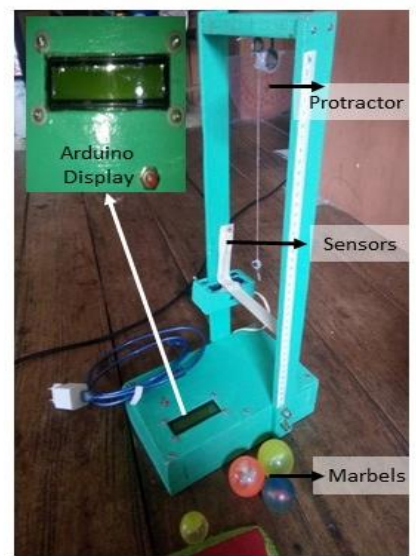

Figure 2. A. Sketch and B. Digital harmonic vibration (DGHS) practicum tool

\section{Result and Discussion}

We report the results of the four stages of developing the DGHS practicum tool in this section. At the definition stage, information was obtained that the harmonic vibration practicum tool in the school still uses a stopwatch in determining the time required to perform the vibration. The practitioner will start the time recording by pressing the start button when it starts and the stop button at the end. This condition opens the opportunity for difficulty in getting the correct data, especially recording the time to make one vibration validly. To cover this weakness, it is necessary to add an automatic switch device by utilizing an Arduino-based phototransistor sensor as a start-stop of a stopwatch so that the vibration time of objects on the pendulum can be monitored accurately.

We then outlined the results in the design stage of a practical tool using an Arduino-based phototransistor sensor and a practical guide for simple pendulum materials. The design is more focused on making practical tools using a phototransistor sensor based on Arduino Uno, while the design of a practicum guide is used to help practitioners implement this practicum effectively and efficiently. We design the practicum tool in a simple form so that it is easy to use, as shown in Figures 2A and 2B. At the development stage or stage 3, we have carried several series of tests out to test the validity of the data generated by the DGHS practicum tool. Among these tests are calibration, validation and practical which are discussed one by one on the following description.

\section{Calibration}

\section{Practical Tool Calibration Using Arduino-Based} Phototransistor Sensor

We did calibration to adjust the DGHS tool that has been designed with existing products. In this practical tool using an Arduino-based phototransistor sensor, what it calibrated is a timer. We carried calibration out in two stages: the measurement of repeated time and comparing the calculated value of practicum gravity with the value of the earth's gravity (see Table 2).

Table 2. The result of Timer Calibration by Comparing the Value of the Earth's Gravity Coefficient.

\begin{tabular}{|c|c|c|c|c|c|}
\hline No & $\begin{array}{l}\text { Time } \\
\text { (s) }\end{array}$ & $\begin{array}{l}g \text {-practice } \\
(\mathrm{g}= \pm \mathrm{g}) \\
\left(\mathrm{m} / \mathrm{s}^{2}\right)\end{array}$ & $\begin{array}{l}\% \text { Error } \\
\text { repeated } \\
\text { time } \\
\text { measure } \\
\text { ment }\end{array}$ & $\begin{array}{l}g- \\
\text { theory } \\
\left(\mathrm{m} / \mathrm{s}^{2}\right)\end{array}$ & $\begin{array}{l}\% \\
\text { Error }\end{array}$ \\
\hline 1 & 9,16 & \multirow{6}{*}{$9.41 \pm 0.20$} & \multirow{6}{*}{$0.08 \%$} & \multirow{6}{*}{9.80} & \multirow{6}{*}{$3.98 \%$} \\
\hline 2 & 9,15 & & & & \\
\hline 3 & 9,15 & & & & \\
\hline 4 & 9,16 & & & & \\
\hline 5 & 9.16 & & & & \\
\hline 5 & 9.16 & & & & \\
\hline
\end{tabular}

The data in Table 2 shows that the results of the calibration of the time calculation on the DGHS practicum tool using an Arduino-based phototransistor sensor obtained through experiments on a simple pendulum with the mass of ball was $0.045 \mathrm{~kg}$, a pendulum string length of $0.20 \mathrm{~m}$, and an angle of 0.045 $\mathrm{kg}$. $10^{\circ}$. The result of repeated time measurement error is $0.08 \%$, and the value of gravity is $9.41 \pm 0.30$. After being compared with the value of earth's gravity with this value, resulting from an error percentage of $3.98 \%$. This data shows that the timer on the DGHS practicum tool is well-calibrated (Rinanthy, 2016).

\section{Measurement}

Data on Experimental Results of DGHS Practicum Tool.

At this stage, we have carried out testing on the DGHS practicum tool. The experimental stage of data collection is to test the suitability of the theoretical relationship with the data obtained from the developed 
DGHS practicum tool. Proof of the suitability of the data for the practicum guide, which is the effect on rope length, load mass, and angle on the vibration period (see Table 3).

Table 3. The Effect of Rope Length on the Pendulum Period.

\begin{tabular}{lllll}
\hline No & $\begin{array}{l}\text { Rope } \\
\text { Length }(\mathrm{m})\end{array}$ & $\begin{array}{l}\text { Time of object } \\
\text { swing 10 } \\
\text { vibration }(\mathrm{s})\end{array}$ & $T(\mathrm{~s})$ & $T^{2}(\mathrm{~s})$ \\
\hline 1 & 0.1 & 6.28 & 0.63 & 0.40 \\
2 & 0.15 & 7.66 & 0.77 & 0.59 \\
3 & 0.2 & 8.88 & 0.89 & 0.79 \\
4 & 0.25 & 9.96 & 1.00 & 1.00 \\
5 & 0.3 & 10.97 & 1.10 & 1.20 \\
\hline
\end{tabular}

Description: Mass of marbels $=0.045 \mathrm{~kg}, \theta=20^{\circ}, \mathrm{N}=$ number of vibrations (10 times)

From Table 3. we can see that the period value increases with the increase in the pendulum's rope length. We can also see the relationship between the variation of the load mass and the period of the pendulum vibration (see Table 4). We also can see that there is no significant shift in the value of the vibration period to the value of the mass of marbles.

Table 4. Relationship between mass to the period of vibration.

\begin{tabular}{|c|c|c|c|c|c|c|}
\hline $\begin{array}{l}\text { Mass } \\
\text { Load } \\
(\mathrm{Kg}) \\
\end{array}$ & $T_{1}(\mathrm{~s})$ & $T_{2}(\mathrm{~s})$ & $T_{3}(\mathrm{~s})$ & $T_{4}(\mathrm{~s})$ & $T_{5}(\mathrm{~s})$ & $\bar{T}(\mathrm{~s})$ \\
\hline 0.007 & 0.851 & 0.85 & 0.85 & 0.851 & 0.85 & 0.85 \\
\hline 0.019 & 0.888 & 0.888 & 0.888 & 0.888 & 0.888 & 0.888 \\
\hline 0.036 & 0.893 & 0.893 & 0.893 & 0.893 & 0.893 & 0.893 \\
\hline 0.047 & 0.865 & 0.865 & 0.865 & 0.865 & 0.864 & 0.865 \\
\hline 0.052 & 0.897 & 0.897 & 0.897 & 0.897 & 0.897 & 0.897 \\
\hline
\end{tabular}

Besides, we can also see that the relationship between the period and the object's mass does not affect the gravity value. The period obtained at various angles of rope deviation resulting in a gravity value is relatively constant (see Table 5). This illustrates that there is no significant effect of the period value on the rope deviation angle. However, the time to make one vibration with an increasing angle of deviation of the rope was also increasing (Tipler, 1998).

Table 5. Relationship between the angle formed by the rope with the period.

\begin{tabular}{llll}
\hline No & angle $(\theta)$ & $\mathrm{T}(\mathrm{s})$ & $\mathrm{T}^{2}(\mathrm{~s})^{2}$ \\
\hline 1 & 50 & 0.900 & 0.838 \\
2 & 70 & 0.910 & 0.848 \\
3 & 100 & 0.915 & 0.865 \\
4 & 120 & 0.920 & 0.883 \\
5 & 150 & 0.925 & 0.918 \\
\hline
\end{tabular}

Description : mass of marbels $=0.052 \mathrm{~kg}, l=0,20 \mathrm{~m}, \mathrm{~N}=$ number of vibrations (10 times).
After the DGHS practicum tool was calibrated, we continue to the validation stage. We give validation instruments to 3 (three) validators, namely two physics lecturers and one physics teacher. Suggestions from the validator for adding units to the result display and the "many vibration" parameter on the LCD display already followed. The three validators gave a very valid DGHS practicum tool with a percentage of $87 \%$ (see Table 6).

Table 6. Results of Validation Analysis of DGHS Practical Tools Using Arduino-Based Phototransistor Sensors (Harmita, 2012).

\begin{tabular}{lclllllll}
\hline $\begin{array}{l}\text { Aspects that } \\
\text { Validated }\end{array}$ & \multicolumn{3}{l}{ Validator } & \multicolumn{2}{l}{ Num- } \\
\cline { 2 - 7 } & 1 & 2 & 3 & ber & score & \multirow{2}{*}{$\%$} & \multirow{2}{*}{ Note } \\
\hline functionality & 12 & 10 & 12 & 34 & 36 & 94.4 & Very Valid \\
Convenience & 13 & 13 & 16 & 42 & 48 & 87.5 & Very Valid \\
Security & 11 & 9 & 12 & 32 & 36 & 88.9 & Very Valid \\
Aesthetics & 15 & 12 & 15 & 42 & 48 & 87.5 & Very Valid \\
Usage accuracy & 13 & 10 & 15 & 38 & 48 & 79.2 & Valid \\
Amount & 64 & 54 & 70 & 188 & 216 & 87 & Very Valid \\
\hline
\end{tabular}

The validation of the DGHS practicum tool using an Arduino-based phototransistor sensor get a percentage in the ranges of $79.2 \%$ to $94.4 \%$. Overall, the practicum tool using an Arduino-based phototransistor sensor is classified as very valid, with an average percentage of $87 \%$. Meanwhile, the results of the validation on the DGHS practicum guide for each aspect (from $79.2 \%$ to $87.5 \%$ ) which was classified as very valid with an average percentage of $83.3 \%$. The material in the practicum guide is under the achievement of practicum objectives. The writing of the practicum guide includes the format for writing the practicum guide. The suitability of the language used is communicative and in accordance with the heterogeneous abilities of practitioners.

To see the practicality of the practicum tool using an Arduino-based sensor, we conducted a trial on second-semester IAIN Batusangkar physics students through practical activities using a DGHS practicum tool using an Arduino-based phototransistor sensor. I gave ten practitioners to fill in the response into the questionnaire after carrying out the practicum and making observations. Data from the practitioner's response through the questionnaire to the practicality of practical tools using an Arduino-based phototransistor sensor can be seen in Table 7 .

Table 7 shows that all aspects of the practicum tools, which were developed using Arduino Uno-based phototransistors get practical responses from the physics students with an average percentage was $85.96 \%$. We can see, the easy read output data of a DGHS practicum tool get the highest percentage of $97.5 \%$ (Sulistiadji \& Pitoyo, 2009). Besides, this condition can create a new atmosphere where students feel happy and easy to carry out practicum (percentage 95\%) (Sanjaya, 2008). The 
curiosity of students to understand the concept of DGHS is also getting better. In the end, students no longer think physics is difficult to understand because we have presented the concepts and proofs through practical and valid experiments (Djamarah \& Zain, 2006).

Table 7. The Results of the Questionnaire Response to the Practicality of Practicum Tools Using Arduino-Based Phototransistor Sensors.

\begin{tabular}{|c|c|c|c|c|c|c|c|c|c|}
\hline \multirow{2}{*}{ No } & \multirow{2}{*}{ Statement } & \multicolumn{4}{|c|}{ Your opinion } & \multirow{2}{*}{$\begin{array}{l}\text { Percentage } \\
\text { (SS) }\end{array}$} & \multirow{2}{*}{$\begin{array}{l}\text { percentage } \\
(\mathrm{S})\end{array}$} & \multirow{2}{*}{$\begin{array}{l}\text { amount } \\
\text { score }\end{array}$} & \multirow{2}{*}{$\begin{array}{l}\text { percentage } \\
\max \end{array}$} \\
\hline & & SS & $\mathrm{S}$ & TS & STS & & & & \\
\hline 1 & $\begin{array}{l}\text { I can understand the use of a simple } \\
\text { pendulum practicum set based on an } \\
\text { Arduino Uno microcontroller }\end{array}$ & 4 & 6 & & & 40 & 60 & 34 & 85 \\
\hline 2 & $\begin{array}{l}\text { I can understand the functions of the } \\
\text { components in a simple pendulum } \\
\text { practicum tool }\end{array}$ & 5 & 5 & & & 50 & 50 & 35 & 87.5 \\
\hline 3 & $\begin{array}{l}\text { It is easy for me to vary the distance of a } \\
\text { simple pendulum practicum tool based on } \\
\text { an Arduino microcontroller }\end{array}$ & 2 & 8 & & & 20 & 80 & 32 & 80 \\
\hline 4 & $\begin{array}{l}\text { I can easily read the output data of a simple } \\
\text { pendulum practicum tool. }\end{array}$ & 9 & 1 & & & 90 & 10 & 39 & 97.5 \\
\hline 5 & $\begin{array}{l}\text { It becomes easier for me to carry out } \\
\text { practicum by using a simple pendulum } \\
\text { practicum tool }\end{array}$ & 8 & 2 & & & 80 & 20 & 38 & 95 \\
\hline 6 & $\begin{array}{l}\text { After using a simple pendulum practicum } \\
\text { tool can improve my analytical skills }\end{array}$ & 4 & 6 & & & 40 & 60 & 34 & 85 \\
\hline 7 & $\begin{array}{l}\text { After using a simple pendulum practicum } \\
\text { tool can improve my curiosity ability }\end{array}$ & 4 & 6 & & & 40 & 60 & 34 & 85 \\
\hline 8 & $\begin{array}{l}\text { After using a simple pendulum practicum } \\
\text { tool, it is easier for me to understand the } \\
\text { concept of physics }\end{array}$ & 3 & 7 & & & 30 & 70 & 33 & 82.5 \\
\hline 9 & $\begin{array}{l}\text { after using a simple pendulum practicum } \\
\text { tool, I prefer to study physics }\end{array}$ & 3 & 7 & & & 30 & 70 & 33 & 82.5 \\
\hline 10 & $\begin{array}{l}\text { After using a simple pendulum practicum } \\
\text { tool, I am not longer think physics is } \\
\text { difficult }\end{array}$ & 4 & 6 & & & 40 & 60 & 34 & 85 \\
\hline 11 & $\begin{array}{l}\text { After using a simple pendulum practicum } \\
\text { tool, I am interested in learning more about } \\
\text { physics }\end{array}$ & 4 & 6 & & & 40 & 60 & 34 & 85 \\
\hline 12 & $\begin{array}{l}\text { I can carry out pendulum practicum } \\
\text { effectively using simple pendulum } \\
\text { practicum tools. }\end{array}$ & 3 & 7 & & & 30 & 70 & 33 & 82.5 \\
\hline 13 & $\begin{array}{l}\text { I can carry out pendulum practicum } \\
\text { efficiently using simple pendulum } \\
\text { practicum tools. }\end{array}$ & 4 & 6 & & & 40 & 60 & 34 & 85 \\
\hline Per & entage & & & & & & & & 85.96 \\
\hline
\end{tabular}

\section{Conclusion}

Based on the results, it can be concluded that the digital harmonic vibration (DGHS) practicum tool using an Arduino Uno-based phototransistor sensor has been successfully developed and calibrated. The results of calibration from repeated time and gravity values measurement were obtained with the percentage of error was $0.08 \%$ and $3.98 \%$, respectively. We have also validated this product in terms of functionality, ease of operation, safety, aesthetics, and accuracy with an average percentage of $87 \%$ or very valid. Lastly, this practicum tool also received a very practical response from physics students at IAIN Batusangkar, with the average percentage of practicality responses was $85.96 \%$.

\section{References}

Deesera, V.S., \& Ilhamsyah, I., Trianto, D. (2017). Rancang Bangun Alat Ukur Gerak Lurus Berubah Beraturan (GLBB) Pada Bidang Miring Berbasis Arduino. Coding Jurnal Komputer dan Aplikasi, 5(2). doi: http://dx.doi.org/10.26418/coding.v5i2.19628 [Indonesian]

Dewi, I. N. A. (2014). Pengembangan alat peraga bandul matematis untuk melatihkan keterampilan proses 
siswa pada materi gerak harmonik sederhana di kelas XI SMAN 3 Tuban. Inovasi Pendidikan Fisika, 3(2). Retrieved from: https://jurnalmahasiswa.unesa.ac.id/index.php Linovasi-pendidikan-fisika/article/view/8094 [Indonesian]

Djamarah, S.B., \& Zain, A. (2006). Strategi belajar mengajar, Jakarta: PT. Rineka Cipta, 124. [Indonesian]

Farasdaq, M. H. (2016). Pengembangan Alat Peraga Bandul Matematis Berbasis Mikrokontroler Arduino Untuk Melatih Keterampilan Proses Sains Siswa SMA: Jakarta: FITK UIN Syarif Hidayatullah Jakarta. Retrieved from: https://repository.uinjkt.ac.id/dspace/handle/1 23456789/49839 [Indonesian]

Harmita, H. (2012). Petunjuk pelaksanaan validasi metode dan Cara Perhitungannya. Pharmaceutical Sciences And Research (PSR), 1(3), 117-135. doi:10.7454/psr.v1i3.3375. [Indonesian]

Humaira, R. (2016). Pembuatan Sistem Pengukuran Besaran Gerak Lurus Berbasis Personal Komputer Menggunakan Sensor Optocoupler. PILLAR OF PHYSICS, $7(1)$. doi: http://dx.doi.org/10.24036/2049171074 [Indonesian]

Maiyena, S., Imamora, M., \& Ningsih, F. (2018). Pengembangan Alat Praktikum Gerak Jatuh Bebas Menggunakan Sensor Phototransistor untuk Pembelajaran Fisika pada Materi Gerak Jatuh Bebas. Sainstek: Jurnal Sains dan Teknologi, 9(1), 54-67. doi: http://dx.doi.org/10.31958/js.v9i1.750

[Indonesian]

Riduwan, M. (2010). Metode dan teknik menyusun tesis. Bandung: Alfabeta. [Indonesian]

Rinanthy, E. P. (2016). Pembuatan Alat Penentuan Percepatan Gravitasi Bumi Menggunakan Metode Pendulum Berbasis Sensor Cahaya LDR. Pillar of Physics, 8(2). doi: http://dx.doi.org/10.24036/2488171074 [Indonesian]

Sanjaya, W. (2008). Perencanaan \& desain sistem pembelajaran. Jakarta: Kencana Prenadamedia Group. [Indonesian]

Sukindar, S., Kartika, I., \& Untoro, N. (2017). The Development of Momen of Inertia Props Based On Arduino Uno for Second Year of Senior High School Student. Proceeding International Conference on Science and Engineering, 1, 229-233. https://doi.org/10.14421/icse.v1.307.

Sulistiadji, K., \& Pitoyo, J. (2009). Alat Ukur dan Instrumen Ukur. BBP Mektan, Serpong. [Indonesian]
Syahwil, M. (2013). Panduan mudah simulasi dan praktek mikrokontroler arduino. Yogyakarta: Andi. [Indonesian]

Tipler, P. A. (1998). Physics for Scientis and Engineer: Jakarta: Erlangga.

Trianto, M. P. (2009). Mendesain model pembelajaran inovatif-progresif. Jakarta: Kencana. [Indonesian] 